\title{
Dois mestres
}

\section{Clovis Bevilaqua}

Ha vinte e cinco anos, J. J. Cardozo de Mello Neto e SPEncer VAmpré ilustram a cátedra do ensino jurídico, falando da Faculdade de Direito de São Paulo, fóco alcandorado da elaboração científica da doutrina e da prática do Direito, cheio de belas e honrosas tradições, poderoso centro de irradiação mental, como a sua irmã gêmea do Norte e como as outras, que vieram depois a pontilhar de luz o território pátrio.

Vinte e cinco anos de ensino. Quanto saber acumularam, no decurso desse tempo, os dois egrégios professores, zelosos no transmitir aos seus alunos idéias sãs e seguras, hauridas na própria experiência, na ciência dos que os precederam em postos semelhantes, no estudo dos escritores nacionais e estrangeiros! Acumularam sabêr, isto é, força espiritual, destinada a expandir-se, a gerar outros centros de força congênere.

Com efeito, as sucessivas gerações de estudantes, que lhes ouviram o ensino, foram, pelo Brasil afóra, aplicar, desenviolvidas e robustecidas, as idéias, que assimilaram, nos vários postos, que o destino lhes assinalou: advogados, juizes, professores, profissionais em vários ramos da atividade social.

E' grande, portanto, a contribuição dos dois egrégios professores para o desenvolvimento e brilho das letras jurídicas em nosso país. E a festa, que lhes faz a Congregação da Faculdade Paulista de Direito, grangeia largos aplausos da gente brasileira, que cultiva as letras jurídicas, porque é justa consagração do mérito e do zelo de dois colegas, 
cujo indefesso labor é produtivo e exerce apreciavel influência na marcha das idéias.

E, referindo-me aos dois estimados confrades, vem-me ao pensamento o primeiro contacto, que tive com a inteligência viva e penetrante de SPEncer VAMpré, depois amigo muito prezado.

Havia eu publicado a Teoria geral do direito civil, onde se encontra um quadro de classificação objectiva dos direitos. Essa representação figurativa dos poderes jurídicos interessou o jovem estudante, que era então SPEncer VAmpré, e sugeriu-lhe a idéia de organizar outro esquema, esprimindo o ponto de vista próprio, e me enviou o seu trabalho. Achei que revelava inteligência arguta e empreendedora e lh'o disse em carta.

Como era de esperar, essa inteligência, que assim se anunciava capacissima, em breve começou a manifestar-se em produções jurídicas de real valor, denunciando individualidade superiormente dotada pela natureza e pelo estudo. Os seus livros, versando o direito civil e o comercial, são de excelente feitio pela firmeza das idéias e sedutora clareza de exposição. A um deles tive o prazer de prefaciar: Interpretação do Código Civil.

As suas Memórias para a história da Academia de São Paulo (2 volumes), além de constituirem a glorificação desse fecundo centro de cultura, dão-nos informações curiosas sôbre a vida e os costumes da sociedade e dos estudantes, que, até certo tempo, formavam grupo inconfundivel, irrequieto e folgazão. E' livro precioso e de leitura atraente esse das Memọ́rias.

Spencer Vampré e Gardozo de Mello Neto entraram para o corpo docente da Faculdade de Direito de São Paulo, em 1917, ano em que tambem ingressou na mesma Congregação Francisco Antonio de Almeida Morato, alta figura, entre as maiores, das letras juridicas brasileiras, a quem os seus pares conferiram o título de Professor Emérito e, ha pouco, o Instituto de Ordem dos Advogados do Rio de Janeiro prestou marcante homenagem. Lembro o fato para 
dizer que o ano de 1917 foi dos felizes para a Faculdade de Direito de São Paulo, tal o valor dessas aquisições.

Nele, os dois mestres, cujas bodas professorais se celebram, lançaram os alicerces da construção, que foram erguendo na mentalidade dos discipulos e agora se estadeia iluminado por vinte e cinco anos de dedicação ao ensino e ao desenvolvimento das letras juridicas no Brasil.

Não está finda a tarefa em que se empenharam; mas a etapa vencida já lhes consolidou a benemerência. 